\title{
The impact of national context effects on HRM practices in Russian subsidiaries of Western MNCs
}

Article

Accepted Version

Novitskaya, O. and Brewster, C. (2016) The impact of national context effects on HRM practices in Russian subsidiaries of Western MNCs. Journal of East-West Business, 22 (1). pp. 127. ISSN 1528-6959 doi:

https://doi.org/10.1080/10669868.2015.1112335 Available at https://centaur.reading.ac.uk/51155/

It is advisable to refer to the publisher's version if you intend to cite from the work. See Guidance on citing.

To link to this article DOI: http://dx.doi.org/10.1080/10669868.2015.1112335

Publisher: Taylor \& Francis

All outputs in CentAUR are protected by Intellectual Property Rights law, including copyright law. Copyright and IPR is retained by the creators or other copyright holders. Terms and conditions for use of this material are defined in the End User Agreement.

www.reading.ac.uk/centaur 
Central Archive at the University of Reading

Reading's research outputs online 


\title{
The impact of national context effects on HRM practices in
}

\section{Russian subsidiaries of Western MNCs}

\begin{abstract}
This paper contributes to the research on comparative human resource management by providing a model of the Russian business system and its impact on HRM practices at Russian subsidiaries of Western MNCs. Whitley's approach was adopted in order to illustrate the links between institutional arenas, business systems, and HRM practices. The empirical part is based on interviews with senior HR managers of Western MNCs operating in Russia. The findings provide insight into the interaction between the national business system and HRM practices in Russia.
\end{abstract}

\section{Introduction}

Russia is the largest European country, and its market potential is very attractive for foreign investors. However, dealing with Russian culture and institutions has proved problematic for many foreign investors (Dixon, et al, 2014). Attempts to understand the situation of foreign investors have had to cope with the complex process of the transition to a market economy and the prevalence of unpredictable informal institutions in Russia. In this paper we focus on human resource management (HRM) practices to answer the question of the impact of national context effects on such practices in the Russian subsidiaries of Western Multinational Companies (MNCs). We use the Business Systems approach developed by Whitley (1999) which has been used before to analyze HRM (Brewster et al, 2015) and is here applied for the first time to the Russian context. 
Western MNCs operating in Russia were taken as the main focus of this research, illustrating how the interaction of various business systems can influence the formation process of HRM practices in subsidiaries of MNCs. This process depends on the interaction effects of the institutional environments of the home- and host-country (Tempel, Wachter and Walgenbach, 2006) in addition to dominance-effects (Edwards and Ferner, 2002) and other external and internal factors like pressures for international integration, the company strategy, structure and micro-political aspects (Almond et al., 2005).

The host-country effects, which include cultural, legal, social, economic, and political systems in the country where a subsidiary is located (Dowling et al., 1999), push MNCs to respond to the local context (Doz, 1986; Morschett and Schramm-Klein, 2010). The home country effects, or country-of-origin effects, on the other hand, represent the set of elements of the behavior of the MNC, which has its roots in the characteristics of the national business system from which the MNC originates (Tempel et al., 2006). At the same time, MNCs might adopt management practices from such dominant economies like the USA, in the belief that these practices would bring success (Almond, 2005). Further, MNC strategies may have an impact as companies may choose to exploit conditions in a particular locale rather than seek for standardization (Rugman and Verbeke, 2004). As a result of the interaction of these different effects, most of the observed practices in subsidiaries are 'hybrid' practices (Ferner et al. 2004: 306). Notwithstanding, identification of local practices among hybrid ones would allow measuring the impact of host country effects.

Figure 1 illustrates the research focus and various impacts on subsidiary HRM practices.

Figure 1. Key influences on the HRM practices of a MNC's subsidiary 


\section{Theoretical framework}

A comparative institutional approach was commonly used by scholars to study how MNCs interact with host county institutions and how this influences their management of human resources (Whitley, 1999; Hall and Soskice, 2001). Notwithstanding, the analysis of capitalisms proposed by Hall and Soskice (2001) cannot be applied to Russia, since they are focused only on developed capitalist economies. Whitley's (1999) theoretical framework of business systems indicates how such a comparative analysis of established market economies can be extended to understand the transformation process from state socialist economies, highlighting both the path-dependent nature of large-scale economic change and the often contradictory effects of institutional transformations (Wachter et al., 2003).

According to Whitley (1999), four major institutional arenas determine the business system of a country and influence national business practices: the regulating role of the state in the economy; the structure of the financial sector and the ways that companies have to obtain access to capital; the education system and the systems for skills development and control; and the cultural values shaping trust and authority in work and managerial relationships. All these elements play an important role in the work culture of a country and in HRM practices. The characteristics of the four major institutions represent specific characteristics of business systems within a country (Table 1). Whitley identified six general types of business systems, which can be found across the globe. They are Fragmented, Coordinated industrial district, Compartmentalized, State organized, Collaborative, and Highly coordinated. Such types of business systems may not match comprehensively with any particular country, but they can be recognized, since their characteristics closely resemble the economic and political state of the studied countries. 


\section{Table 1 Institutional features associated with different types of business system}

Further, the theory suggests the ways in which firms differ between business systems and their relations with particular features of dominant institutions. Whitley distinguishes between five "ideal kinds of firms which vary principally in how much owners and managers can share risks and commitments, and with whom, and in the sort of strategies they develop" (Whitley, 1999: 75). For example, opportunistic firms can often be found in state-owned or controlled, developing economies; while artisanal firms are dominant in Japan.

The next layer of Whitley's model discussed the work systems, which were linked to certain types of firms and characterized by "contrasting ways of structuring tasks and jobs, of controlling how work is allocated, performed, and rewarded, and of structuring employment relationships" (Whitley, 1999:88). In order to illustrate these work systems, Whitley provided examples of various economies, where a particular work system prevailed. So a Taylorist work system was typical for compartmentalized or state-guided business systems, while a Negotiated system prevails where there were collaborative business systems.

So following the links between the characteristics of four institutional arenas, key dimensions of six business systems, types of firms and all the way down to work systems, the theory enabled the identification of the common aspects for certain economy and human resource practices (Figure 2).

\section{Figure 2. Whitley's Business System Framework}

\section{Host Country Effects or Russian Business System}

Based on Whitley's theory, there is a possibility of identifying the most common characteristics, and consequently, the types of business system, firm, work system, and 
eventually HRM practices in Russia. Figure 3 presents the conceptualized model of the Russian context according to the theoretical framework.

\section{Figure 3. Conceptualized model of Russian context}

In describing the model presented above, it is important to note that each level of the model is interlinked with the others. This helps us to build propositions for this research.

\section{Institutions}

a. State structure and policies.

Russia's state structure after the collapse of the USSR did not significantly change. Puffer and McCarthy (2007:4) noted: "government retained an ownership position in thousands of enterprises that were privatized, giving it ability to influence or block important strategic decisions within those firms". The state retains monopoly control of the natural gas industry and of oil export pipelines (Hanson and Teague, 2005). Since Putin reestablished central control, the state has become unified and a stronger interlocutor, able to assert itself over private interests. Consequently, 'the state takes a more 'dirigiste' approach in stricter regulation of all other segments of economic activities" (Gurkov and Zelenova, 2008:4). Under Putin, the state began to directly or indirectly control large Russian corporations. The small business sector became very weak (Basareva, 2011) due to the institutional trap, as this segment is restricted by widespread corruption. Despite the state's power, formal regulatory institutions are not sufficiently developed to guide decisions (Galiulina, 2011), and therefore business people have relied upon informal institutions for decision-making. As a result, the Russian economy lacks intermediates (Zudin and Golikova, 2011) and horizontal and vertical integration. Cooperation between competitors is very weak (Hanson \& Teague, 2005). Because of political risks, business owners are usually directly involved, creating vertical 
integration of ownership. In addition, state coordination mechanisms lack transparency, forcing owners to control their businesses tightly and hold personal political negotiations. According to Whitley (1999), such a situation corresponds to the 'state-guided' business system, with widespread Taylorist and patriarchal work systems, characterized by low taskfragmentation, high managerial control, low worker discretion, high separation of workers from managers, low employer commitment, and job-based rewards or personal evaluation of performance.

\section{b. The banking and financial system.}

Banks in Russia have not been willing to risk their money with many Russian enterprises. Banks are wary of the financial risks posed by enterprises and their lack of legal recourse in an economy where nonpayment of debts is epidemic. As a result, many banks concentrate on a few customers they know well and on taking control of companies. Foreign banks offer little relief for Russian enterprises. They have been drawn into the Russian government securities market, which offers high yields and none of the complications of lending money to troubled industrial firms (Blasi et al., 1997) even though "in the still undeveloped financial services sector, some organizations have begun to provide the foundation for capital markets" (Puffer \& McCarthy, 2007:5). The undeveloped capital market sector consists of large and midsized privatized companies that are not yet actively traded. Such a financial system, based on credit, produces low cooperation among competitors and low employer-employee interdependence (Whitley, 1999). Companies experience high employee turnover, and therefore are not willing to invest in personnel development. In such an environment, there is a high separation between manager and worker. The credit-based financial system would place profit gain ahead of growth, and thus would include profit sharing in compensation packages and would appraise employees based on results and financial output. Rewards 
would be tied to the employee's position instead of skills or potential, and decided upon according to short-term financial results.

\section{d. The development, organization and control of skills.}

Walker (2006:1426) stated that: "having become dislocated from industry after the collapse of the Soviet Union, Vocational Training Colleges (Profuchilishche) recently became the subject of decentralizing reforms intended to make them more responsive to local labor market demand". Young people still experience problems in entering the labor market, and therefore choose to spend more time in education, or to experiment with a number of different jobs. 'Getting on' in Russian companies is related more to personal connections and less to skills and education (Bjorkman et al., 2007a). Due to the gaps in Soviet public education, business practitioners in modern Russia are deficient in their knowledge of business strategy, marketing, finance, human resource management, international trade and foreign languages (Vlachoutsicos and Liargovas, 1999).

The role of trade unions in Russia has also changed dramatically. Traditionally, Russian trade unions focused on the redistribution of social benefits and limited exchange of information with workers. Today, Russian trade unions are losing their power (Kozina, 2009) and do not represent a viable force (Gurkov and Zelenova, 2008). Trade unions lack the institutional and financial resources to increase their membership, provide legal advice and represent workers in the courts to support rank-and-file action against employers (Clarke, 2004). Although the formal apparatuses of collective bargaining, labor contracts and tripartite collaboration have been installed and the formal independence of the judiciary guaranteed, it has been difficult for trade unions to adapt to their new role (Blasi et al., 1997). Instead, negotiations for employees' compensation have begun to be conducted on the individual level (Cheglakova, 2008). According to Whitley (1999), the collapsed vocational training system forces MNCs 
to implement more extensive training and decentralized bargaining would reproduce individual negotiation for compensation.

e. Trust, authority and loyalty.

Many authors argue that modern Russian managers have no trust in government, lack "transparency in dealing with authorities" (Camiah \& Hollinshead, 2003:254) and have little respect for "senseless" laws (May, Puffer, McCarthy, 2005:26). "Mutual trust often exists within closed networks of personal relationships" (Engelhard and Nagele, 2003:269). As a reaction to such mistrust, relationships of blat (corruption) became vital "to gain such benefits as building trust in inter-enterprises relations, security of business partners and clients, governmental support of business activities, and access to the required resources" (Butler and Purchase, 2004:34).

The management style of the Soviet enterprise can be characterized as 'authoritarian paternalist', with the enterprise director having absolute authority in the enterprise (Clarke, 2004:8). The director would not be willing to delegate responsibilities due to the lack of formal procedures. According to Whitley (1999), the low level of trust encouraged direct supervision of work processes and an unwillingness to delegate control to managers through formal procedures.

\section{The Business System Characteristics}

Following the theoretical model, it is important to elucidate the business system characteristics that Whitley (1999) groups into three categories: ownership coordination, nonownership coordination, and employment relations.

\section{a. Ownership coordination.}

Because privatization was focused on distribution of state welfare among employees, today the dominant shareholders in Russia are employees and midlevel managers. Yet, these 
shareholders have limited influence on management; none of them are strategic investors or management experts (Blasi et al., 1997). In the case of MNCs or banks, those who own the majority of shares tend to take control of the companies (Blasi et al., 1997). Large corporations are centralizing management functions and strategic decision making in their holding companies (Clarke, 2004). In the oil and gas and metallurgical sectors especially, vertically integrated holding companies have developed, in which companies acquired supplier and processing enterprises to establish an integrated production chain. Horizontally integrated holding companies have developed in sectors dominated by a relatively small number of large producers of standardized products. In an economically and politically uncertain environment, companies integrate in order to strengthen the position of existing subsidiaries by securing control of their suppliers and markets (Clarke, 2004).

\section{b. Non-ownership coordination.}

In Russia, there is no consensus or cooperation between large firms across major policy issues. The major obstacle to cooperation between competitors in Russia is a lack of available information (Hanson and Teague, 2005). Golovanova and Kadochnikov (2011) showed that despite the very low vertical and horizontal integration of machinery manufacturers, the IT sector is more integrated in Russia. Zudin (2011) underlined the tendency of Russian large and midsize companies to enter into business associations, which currently represent $54 \%$ of companies. Such associations aim to lobby the government, and play an important role in supporting new presidential candidates and representatives of the leading political parties.

\section{c. Employment relations and work management.}

The international business community has made much of the problems presented to business by the absence of the rule of law in post-Soviet Russia. The two parties in a business agreement stand on more or less equal footing, so that there is a substantive equality 
underlying the formal equality of the contract. The absence of an effective judicial system is inconvenient, but MNCs have proven to be adept at adapting to 'local customs', using 'commission payments' and employing 'security companies' to secure and enforce contractual agreements with Russian partners. However, little attention has been paid to the impact of this absence of a rule of law on the position of labor. The situation with the labor contract is different, because there is a fundamental asymmetry of power and resources inherent in the wage relation. The fragile relationship between Russian workers and managers is marred by a history of mistrust and suspicion (May et al., 1998).

The government favors collective agreements and promotes their wider use in large companies, but for small and medium-size businesses, the situation is different. There are no active trade unions in small businesses, and workers are usually powerless against an employer's arbitrary rule because local controlling bodies (trade inspectors) rarely interfere. However, when an employee brings a case to court, Russian courts are inclined to take the side of an employee as a 'presumed victim'. Thus, the threat to bring the case to court often serves as a strong argument in individual labor disputes (Gurkov and Zelenova, 2008).

Manager-worker relationships differ according to the type of company. In Russian enterprises, there is a virtual 'obsession' among some managers to manipulate and control employees in order to maintain their own positions (May et al., 1998). In the case of MNCs, line managers have less power within a strict hierarchical structure. In any company, there is a strong differentiation between core and peripheral employees, and the latter are often discriminated against (Kalabina, 2011).

Employer-employee interdependence is stronger in large local companies, where a career path can develop within the company and compensation depends on how long an employee has worked at the company (Kalabina, 2011). In other cases, the Russian labor market has high turnover and employer-employee interdependence is fairly weak. 
According to Whitley (1999) low employee involvement in decision making is represented by performance appraisal, higher job standardization and simplification, so that skilled workers could be replaced by unskilled and cheaper ones. Rewards are based on the amount of standard outputs produced by each role incumbent, as distinct from their specific skills or personal capacities, and do not reward workers' initiatives in solving problems.

Based on the above information and Whitley's theory, Tables 2 shows the linkages between business system characteristics, institutional features, and HRM practices.

Table 2. Theoretical links between institutional features, business system and HRM practices.

Reflecting Table 2, the following propositions were formulated:

Recruitment and Selection

1. The weak public training system forces companies to recruit via personal contacts and select experienced employees.

Training and Development

2. Undeveloped vocational training in business and gaps in Soviet public education result in deficiencies in knowledge of business studies and foreign languages, and employees require extensive training in those areas.

3. The financial system based on credit reproduces low employer-employee interdependence. Companies experience high employee turnover, and therefore are not willing to invest in personnel development.

Performance Management

4. A low-trust environment discourages employees' involvement in decision-making; employees are evaluated based on results. 
5. Due to the lack of formal procedures and mistrust, managers are not willing to delegate responsibilities, instead preferring direct supervision.

\section{Compensation and Benefits}

6. Weak trade unions and decentralized bargaining allows individual negotiation for compensation and high wage differentials.

7. In credit based financial systems rewards are tied to the employee's position, instead of skills or potential, and compensation packages include profit sharing.

\section{HRM practices in Russia}

In order to confirm these propositions we examined traditional HRM practices used in Russian enterprises. First of all, it is important to mention that the concept of HRM in Russia is considered to be new (Fey et al., 1999). In Soviet times, the function of HRM was largely decentralized among five units responsible for personnel issues. As Gurkov and Zelenova (2008:9) described it: "The local Communist Party committee supervised general social atmosphere and had the final voice in all promotions. The personnel department dealt with routine functions of legal paperwork in hiring, firing, and performance assessment. The local trade union was responsible for social life, including holiday camps, kindergartens, sports and social events, and the most important issue, allocation of housing among employees. The salary department was responsible for salary administration. Finally, the special unit in direct supervision by the Chief Engineer dealt with issues of job design and work safety. Such decentralization meant that there never has been a clearly articulated human resource strategy at enterprise levels".

Even twenty years after the fall of the central planning system, personnel departments still do not manage human resources according to the requirements of western textbooks. In most cases, personnel departments are separated from strategic decisions and cannot advise 
executives even on HRM issues (Gurkov et al., 2009), occupying the lowest rank among all functions in a company. There is no HRM strategy within the department (Gurkov and Zelenova, 2008), with line managers taking charge of HRM. However, there has been a positive trend in the last few years of implementing successful HRM practices in Russia (Dixon et al., 2014)

\section{a. Recruitment and Selection}

The hiring process is challenging because of Russia has a heterogeneous population in terms of the level and quality of education, expectations, and values, along with very weak information flows (Fey et al., 1999). Headhunter firms play an important role, and firms also use newspaper advertisements; personal contacts remain widely in use, as is traditional in Russia.

Because of the lack of capability of their HRM departments, Russian companies prefer candidates who are capable of adjusting to a position as quickly as possible without any special training from the company side. Candidates' connections with authorities are considered an important element in decisions about a recruit. Such candidates are recruited mostly through personal connections. Today, the Internet has become an important source of information for both employees and employers. Among all the variety of selection procedures possible, interviews and probation periods are the only two forms employed in most Russian companies. In Russia, the probation period is considered not as the beginning of real employment, but as a means by the employer to save on salary and benefits. In some cases companies terminate relations with an employee after the probation period without paying any salary.

\section{b. Training and Development}

Training among Russians is much needed (Gurkov and Zelenova, 2008); however, "the majority of new private employers make very little provision for the training of their 
employees" (Clarke and Metalina, 2000:19). Companies mostly outsource training programs for key personnel to specialized providers. The government also organizes a "large-scale program with intensive theoretical classes," followed by practical knowledge exchange with Western companies (Gurkov and Zelenova, 2008: 21). Recently, new business educational institutions providing MBA diplomas have appeared in Russia. Russian managers have limited traditional management training and coaching skills (Fey, Bjorkman and Pavlovskaya, 2000), and there have been calls to spend money on employee training (Shekshnia, 1994).

\section{c. Performance Management}

According to Gurkov and associates (2009) the performance management of workers and front-line employees is based on direct observations and the registration of the quality and quantity of work by the supervisor. At the same time the authors noted that the formal appraisal system in Russia is considered to be very weak (Gurkov et al., 2009).

\section{d. Compensation and Benefits}

From a legal perspective, the "official system of reward management is based on two pillars - the minimal wage and a tariff system," where the tariff system "scales wages according to the complexity of particular work and the relative level of payment for particular jobs of various complexities" (Gurkov and Zelenova, 2008:15). A wide dispersion of salaries is linked with a reluctance to reveal real incomes. In the case of a large corporation, a kind of reward system like stock-related rewards and profit-sharing schemes is used for top managers (Gurkov et al., 2009). Other types of compensation are used for all employees, such as social benefits (health insurance, meal and transport allowances, holiday allowance, educational allowance), and the thirteenth month salary is very common in Russia.

Geographical divergence in compensation packages is a major issue for the country. As Oshchepkov (2009:4) noticed, "in the current situation, both groups of high- and low- 
income regions form separate convergence clusters that, in the absence of an appropriate federal policy, will have a tendency to diverge from one another."

The literature review on local HRM practices in Russia revealed that theoretical assumptions are relevant. Scholars have observed in Russia most of HRM practices suggested by the theory. This also confirms the correct identification of the business system type for Russia.

\section{Methods and data collection.}

The research explores the new context of transition economy and the impact of context on HRM practices in MNCs operating in Russia, applying theory that has never been tested there before. Consequently, a qualitative approach represents the most suitable way to discover new relationships between institutions and MNCs. Surveys in this case would not be appropriate since there is not yet sufficient coherence in HRM in Russia to be sure that respondents will interpret questions similarly. To assess the position of foreign subsidiaries operating in Russia we used interviews and case studies. Structured interviews were conducted with the HRM Directors and line managers of 12 Russian subsidiaries of large MNCs, leaders in their industries, originating from the USA, Germany, France, Switzerland, Sweden, Denmark, and Korea. Organizations were selected for size, subsidiaries with at least 100 employees, and ownership, more than $75 \%$ of foreign. Because Moscow is the most developed region in Russia and has the highest number of MNCs operating there, and for reasons of practicality in this vast country, we limited our study to the Moscow region. The sample included a variety of industries, both in manufacturing and in services. Most of the subsidiaries were brownfields.

An interview guide was adopted from Wachter et al (2003) and combined with a schedule used to structure the interview. Discussion was encouraged but we also used some closed-ended questions. The interviews were conducted in Russian. All interviews were recorded, transcribed and then translated in English. Results were presented and discussed with academic and professional experts in Russia.

The first part of each interview was focused on contingency factors, such as date of foundation, size of company, etc. The next part used closed questions on work systems 
adopted from Whitley (1999). Respondents were asked to indicate on a five-point Likert scale the degree of company commitment to retaining its core workforce and provide employment security, degree of task fragmentation and specialization, degree of worker discretion over how tasks are performed and involvement in problem solving, degree of separation of, and segmentation between, managers and workers in their backgrounds and skills, and degree of delegation of responsibilities. Then we focused on the coordination mechanisms employed by HQ. Here two different types of control, formal and informal were incorporated into questionnaire, following Martinez and Jarillo (1989). Out of a total of seven questions in this section the first four represented formal parent control including centralized, formalized and output control and planning, while the remaining three questions correspond to informal control socialization and networks (Myloni et al. 2006). In addition, we discusses several questions on HQ's resources dependence, number of expatriates, and type of structure and strategy. Finally, the interviews ended with questions about HRM policies and practices and their transfer to Russian subsidiaries. Some were adopted from Bjorkman and Ehrnrooth (2000), asking respondents to indicate on a five-point Likert scale whether their subsidiary's HRM practices were more similar to home country practices or to host country practices as an attempt to get their assessment of the way that Western MNCs adapt to local conditions in Russia. During the interview the respondents were asked to describe in detail their HRM practices based on four categories: recruitment and selection, training and development, performance management, and compensation and benefits. The accent here was on identifying whether the HRM practices described in theoretical positions were in place, and if so, was it the national context effect or influence from HQ that predominated.

Qualitative data was analyzed in tabular form, wherein all interviews were combined in one Excel file to compare the answers. The first column of the document had analytical categories, and successive columns contained responses from the interviews. A comparison 
of respondents' answers was possible in the horizontal axis. Color-coding was applied to highlight the differences in the origin of studied companies.

\section{Findings and Discussion}

Whitley (1999) described the work system, shaped by local institutions, as an important influencing factor on HRM practices. We have described the typical Russian work system including low employer commitment, low task-fragmentation, low employee involvement, high worker-manager separation, and low delegation.

Results show that US companies were more successful at retaining key employees, but every company worked on retention programs. Task fragmentation was also higher in US companies, with an algorithm of actions even for sales positions. European manufacturing companies had high task fragmentation only for technical positions. For service industries, blue collar workers' involvement in problem diagnosis and solving was generally high, with two exceptions at manufacturing plants of US and French companies.

The degree of separation between managers and workers (or lower ranking employees for service industries) was higher in French companies and lower in US ones. The difference in vacation duration underscores the degree of separation. French companies provided extra vacation days for managers, as did one US company, whereas a German company had the exact same length of vacations for managers and workers.

None of the companies had the same work system as Russian domestic firms, although certain elements of the work system were found in each company. Table 3 summarizes the work systems in studied companies.

Table 3. Work system at Russian subsidiaries

\begin{tabular}{|c|c|c|c|c|c|c|}
\hline \multirow[t]{2}{*}{$\mathbf{N}$} & \multirow{2}{*}{ Company origin } & \multicolumn{5}{|c|}{ Work system } \\
\hline & & Commitment & Fragmentation & Involvement & Separation & Delegation \\
\hline 1 & US & high & some & high & low & high \\
\hline 2 & US & high & some & high & some & high \\
\hline 3 & US & high & high & low & some & some \\
\hline 4 & US & some & some & some & some & some \\
\hline 5 & German & high & some & high & some & high \\
\hline 6 & French & some & low & high & high & some \\
\hline 7 & French & some & some & some & some & some \\
\hline 8 & French & high & some & high & high & high \\
\hline 9 & Swiss & high & some & high & some & high \\
\hline 10 & Sweden & high & some & some & low & some \\
\hline 11 & Korea & high & some & high & high & some \\
\hline
\end{tabular}




\begin{tabular}{|l|l|l|l|l|l|l|}
\hline 12 & Sweden & high & high & some & some & high \\
\hline
\end{tabular}

As for each subsidiary's dependence on HQ's financial resources, subsidiaries of US companies were reported to be more controlled and more dependent, whereas other companies allowed subsidiaries relative autonomy. The same difference was observed for personnel dependence, in that US companies had more centralized planning and control, whereas European companies allowed the subsidiaries more freedom and HQ appointed executive positions only. Consequently, US companies tended to use more global strategy with some local adaptations, whereas European companies mostly used a strategy adaptable to the domestic context.

American companies executed stronger formal and informal control over their subsidiaries, providing them with written policies, rules and regulations, detailed planning, regular managers' trainings and informal communication channels. In contrast, the French companies demonstrated a higher degree of autonomy, with considerable freedom in following HQ's recommended guidelines, except for the production sites, which had strict rules and regulations with high control from the French HQ. German companies had a level of control similar to the French companies', but with more detailed planning.

Managerial control within the subsidiary was higher in American companies. The French companies aimed for subsidiaries to work independently. Control mechanisms such as integrated information systems were difficult to use in most of the companies because of the foreign language knowledge requirement. Two American companies claimed that they are integrated into the corporate information system, whereas others expressed the desire to be connected or to use a parallel system in the local language.

Practices such as productivity comparisons between subsidiaries, formulated corporate culture and international transfer of best practices were common for every company. However, international standards were not applied in the German and Swedish companies, as they argued that different markets have different goals.

Expatriates had the role of controlling authorities, holding the top executive positions (CEO, CFO) in all these companies. Because expatriates' salaries are covered in the subsidiary's budget, there are fewer of them, with the exception of companies in which expertise transfer is vital for business success. For these companies, independent of origin or industry, the number of expatriates equalled $15 \%$ of the total headcount.

Every subsidiary of these multinational companies considered HRM important. The HR director was usually on the board of directors and was included in decision-making on 
matters other than HRM strategy, indicating a strong home-country effect (Proposition 7), whereas in Russian companies the HRM department was much less empowered. Only two of the Russian subsidiaries had trade unions, and they had a very weak influence on HRM processes.

Table 4 summarizes the coordination mechanisms described above; the factors in bold are the ones that would have the highest extent of localization.

Table 4. Coordination mechanisms at Russian subsidiaries

\begin{tabular}{|c|c|c|c|c|c|c|c|c|}
\hline \multirow[t]{2}{*}{$\mathbf{N}$} & \multirow[b]{2}{*}{ Origin } & \multicolumn{7}{|c|}{ Coordination mechanisms } \\
\hline & & Strategy & Structure & Control & Expatriates & Role of HR & $\begin{array}{c}\text { Trade } \\
\text { unions }\end{array}$ & $\begin{array}{c}\text { HQ } \\
\text { dependence }\end{array}$ \\
\hline 1 & US & Transnational & Matrix & Strict, F/I & $1 \%$, top & High & no & Strong \\
\hline 2 & US & Global & Product & Strict, F/I & $15 \%$, top & Some & no & Strong \\
\hline 3 & US & Transnational & Matrix & Strict, F/I & $1 \%$, top & High & weak & Strong \\
\hline 4 & US & Transnational & Matrix & Strict, F & $1 \%$, top & High & no & Strong \\
\hline 5 & German & Multi-domestic & Geographic & Some, F/I & $1 \%$, experts & High & no & Weak \\
\hline 6 & French & Global & Product & Some, $\mathbf{F}$ & $15 \%$, top & High & no & Some \\
\hline 7 & French & Multi-domestic & Geographic & Low & $0.3 \%$, top & High & weak & Weak \\
\hline 8 & French & Transnational & Matrix & Some & - & & & Some \\
\hline 9 & Swiss & Transnational & Matrix & Strict, F/I & $1 \%$, top & High & & Some \\
\hline 10 & Sweden & Multi-domestic & Geographic & Low & $1 \%$, top & High & & Some \\
\hline 11 & Korea & Global & Product & Strict, F/I & $5 \%$, both & Some & no & Strong \\
\hline 12 & Sweden & Global & Product & Low & $0 \%$ & Some & no & Weak \\
\hline
\end{tabular}

Internal factors discussed above might facilitate or constrain the process of transferring HRM practices from Western HQs to Russian subsidiaries. Table 5 shows the extent of standardization of HRM practices. Three companies $(5,10,12)$ have a significantly low level of standardization. Table 4 indicates that such localization could be explained by subsidiaries' weak dependence on HQ's resources and the absence or small number of expatriates, who usually require a standard approach to their employment across the globe. A low level of control through formal and informal procedures also contributed to the autonomy of Russian subsidiaries in these companies.

In contrast, companies 1, 3 and 4 show a high level of standardization of HRM practices at their Russian subsidiaries. All of these companies are of US origin, and have an ethnocentric approach.

The Korean company has a global strategy, strict control, and strong dependence on HQ's resources, therefore HRM practices are fairly standardized. 
Table 5. Standardization of HRM practices at Russian subsidiaries

\begin{tabular}{|c|c|c|c|c|c|}
\hline \multirow{2}{*}{$\mathbf{N}$} & \multirow{2}{*}{ Origin } & \multicolumn{4}{|c|}{ Standardization } \\
\cline { 2 - 6 } & & R\&S & T\&D & C\&B & PA \\
\hline 1 & US & some & high & high & high \\
\hline 2 & US & high & some & some & high \\
\hline 3 & US & high & high & high & high \\
\hline 4 & US & some & high & high & high \\
\hline 5 & German & low & low & low & low \\
\hline 6 & French & low & some & some & low \\
\hline 7 & French & some & some & high & high \\
\hline 8 & French & some & some & some & some \\
\hline 9 & Swiss & high & high & high & high \\
\hline 10 & Sweden & low & low & low & high \\
\hline 11 & Korea & some & some & some & high \\
\hline 12 & Sweden & low & low & low & low \\
\hline
\end{tabular}

The theoretical propositions describe local HRM practices, which are shaped by National Business System and therefore should be found in companies operating in this environment. However, in MNCs there are other factors that might influence the process of HRM formation. In this article we concentrate on those HRM practices shaped by the Business System. Among such practices we have observed in the Russian subsidiaries the following: recruitment through personal contacts, selection of experienced employees, extensive training, direct supervision, individual negotiation for compensation, personal evaluation of performance, high reward differentials, profit sharing rewards, and appraisal for results or financial output. Table 6 presents a summary of research, listing local HRM practices at Russian subsidiaries of Western MNCs.

Table 6. Local HRM practices at Russian subsidiaries of Western MNCs

\begin{tabular}{|c|c|c|c|c|c|c|c|c|c|c|}
\hline $\mathrm{N}$ & Origin & 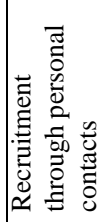 & 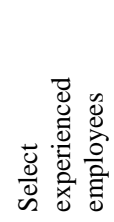 & 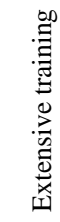 & 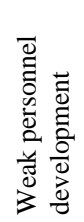 & 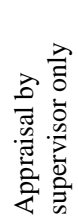 & 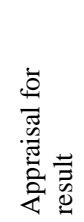 & 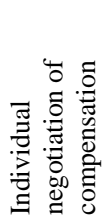 & 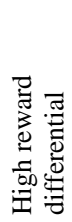 & 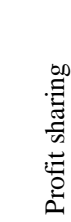 \\
\hline 1 & US & & + & + & & & & & & \\
\hline 2 & US & + & + & + & & & + & + & & \\
\hline 3 & US & & + & & & & + & & & + \\
\hline
\end{tabular}




\begin{tabular}{|l|l|l|l|l|l|l|l|l|l|l|}
\hline 4 & US & + & + & + & & & & & & \\
\hline 5 & German & + & & + & & + & + & + & & \\
\hline 6 & French & + & + & + & + & & & + & + & \\
\hline 7 & French & & + & & + & & & & + & \\
\hline 8 & French & & + & + & + & & + & & & \\
\hline 9 & Swiss & & & + & & & & & & \\
\hline 10 & Sweden & + & + & + & & + & & & & \\
\hline 11 & Korea & + & & + & & & & & & \\
\hline 12 & Sweden & + & + & & & + & + & & & \\
\hline
\end{tabular}

Despite an assumed convergence resulting from the globalization process and the weakness of formal institutions in a host environment, MNCs adapt to the Russian context to a high extent. National cultural and institutional features force practices to mutate. Below, we describe examples of several HRM practices, which were adapted to the Russian environment, and their related reasons.

\section{Recruitment and Selection}

Scholars who studied HRM practices at Russian subsidiaries argued that the hiring process in Russia is very challenging due to the very weak information flow and the more heterogeneous population in terms of level and quality of education, expectations, and values (Fey, et al., 1999). Therefore, MNCs have to rely mostly on headhunter firms that play intermediate roles between the company and job seekers, as well as advertisements in newspapers. Our empirical study of Western MNCs in Russia has supported these arguments, observing in all cases the use of headhunter firms in big cities and advertisements in newspapers in remote areas. As with Russian companies we found extensive use of personal contacts and referrals. This approach was always considered as a part of Russian culture and has successfully found its application in modern business, where MNCs benefit from it as well.

As for selection criteria, two additional points were important for all the MNCs: education and competence. Typical for Russia, personal connections were desired in a few companies for top managers. Graduate recruitment was still represented in US companies, 
while most of the French and German companies expressed unwillingness to invest in a longterm development strategy. An international manager pool was observed in every company.

According to Whitley's theory (1999), which describes a typical Russian firm as being 'opportunistic' with low investment in employee development, the main selection criteria in the Russian context would be experience. In the case of these MNCs, we found that employers were looking for candidates with previous work experience at a foreign firm as the main selection factor, and making little use of internships. All the studied MNCs strictly follow Russian labor law and hire employees after 3 months of probation.

\section{Training and Development}

Training is crucial in Russia because of the historical heritage of the Soviet Union, where a strongly centralized government system and educational gaps in business management put them far away from the Western market-oriented capitalism model.

Many empirical studies confirm that in Russia, employees receive more training than in Western countries (Bjorkman's et al., 2006). In countries like Russia, training can be remedial, compensating for weaknesses in the education system (Goergen et al., 2012) or it can be an important source of competitive advantage (Jukova and Korotov, 1998; Zhukova and Korotov, 1998). Despite significant coordination of training and development programs from headquarters (Fey, et al., 1999), the content of training is less standardized in Russia, and it is provided in the local language for higher effectiveness (Bjorkman and Ehrnrooth, 2000). These arguments are totally in line with our findings, where subsidiaries reported use of extensive training programs for all ranks of employees, which are provided locally in the local language, as well as at headquarters or world leading business schools for top management.

The annual budget planning in different companies is tied to different references. In some cases, the planning is done according to the salary fund, while in others, planning for 
KPI, headcount, and budgets for training programs are done according to the financial results of the previous year. Therefore, the frequency of providing such training also varies among companies. A minimum of 2-3 training sessions per year is offered by any company. For workers, it is mostly in the form of mentoring (for a German company) and online courses (for a US company), while for managers, it is usually in-class courses.

As for topics, every company had courses in its arsenal like sales and marketing, effectiveness and leadership, and various technical training. Language courses were found in just a few companies. Development programs in most of the cases have an international character. The major difference between the studied companies was found at the level of the HQ's influence on training and development programs. For US companies, such influence was high, with many courses being standardized and diffused to the subsidiary. In contrast, the influence is very low for the German company, where the subsidiary is free to design and select needed courses. The French HQ has some influence, playing the role of adviser and sending recommendations to its subsidiary.

\section{Appraisal}

In contrast to other HRM practices, which were fairly closely adapted to the local environment, in MNC Russian subsidiaries, a performance appraisal system and criteria used to determine promotions have been found to be highly standardized (Bjorkman and Ehrnrooth, 2000). Despite the culturally appropriate top-down evaluation in Russia, where superiors evaluate the subordinates, MNCs successfully added a reciprocal process (Fey et al., 1999). However, feedback at this point is most positively indirect, reflecting the low amount of individualism in Russian culture. Direct feedback may cause irreparable damage to the employee's self-image and ruin loyalty to the organization (Elenkov, 1998). Referring to Whitley's theory (1999), in a Russian firm, personal evaluation of performance and appraisal are common for determining results or financial output. 
In our study, every company had an appraisal system based on various KPIs, with a common process of employee self-evaluation followed by an interview with the supervisor in which weaknesses and opportunities were discussed. In contrast to the German companies, in US and French companies, the appraisal process also involved peers and subordinates. As for the subject of evaluation, US companies differed from others in their stronger orientation toward results rather than toward the process of achieving the results. The appraisal system reported by US companies used a global standard practice diffused from HQ. In the German and French companies, the appraisal system was developed locally and had little influence from HQ. Among conflicting practices in the US subsidiary, it was found difficult to fire inefficient employees. Because of Russian labor law, a company cannot fire an employee in Russia as easily as in the USA.

\section{Compensation and Benefits}

The compensation system in Russia has to deal with a high turnover of employees (Shekshnia, 1998) so practices typical elsewhere may not be directly applicable (Mueller and Clarke, 1998). Research has found standardized performance based compensation systems, which was controlled from MNC headquarters (Bjorkman et al., 2007) with the salary structure is determined with input from the subsidiaries (Fey et al., 1999).

Using Whitley' (1999) terminology, the Russian context produces individual negotiation for compensation with high reward differentials and profit sharing rewards. The decentralized bargaining is explained by the weakness of trade unions and low cooperation among competitors. Worker-manager separation in their rewards occurs due to the cultural feature of high power distance. Finally, profit sharing rewards result from an unstable economy where employers tie compensation to the company's business cycle.

Our research supported all the above statements, finding in all studied companies a fixed salary and a high proportion of premiums as compensation tools. Rewards were tied to 
the individual performance of employees or the financial results of the company. Another adjustment of compensation practices to the Russian context was the use of fixed term contracts, which helped to balance the unstable market environment and avoid difficulties of laying off people. So, a company usually hires term workers for the high season to cover the workforce deficit in the production line. In the US companies, short term employees are also in sales positions, which allows an employer to filter high potential employees easily.

The degree of HQ influence on compensation policies was widespread, although the amounts were adjusted to local market conditions. Several of the MNCs said that their compensation and benefit system was developed in the subsidiary, and HQ had no other influence than recommendations. Respondents also noted that the compensation system was not influenced by trade unions. US and German companies had collective agreements. In general, trade unions are barely represented in these companies. Instead, some subsidiaries had organized an internal works council (Sovet trudovogo collectiva). This body helps workers, organizes sport events, and serves as a direct connector with the management of the company. The only reported conflict with a trade union was in one US company.

Non-monetary benefits are important in the Russian context, and may serve as a retention tool (Fey et al., 1999). Practices include training, corporate cultural events, free meals, social activities, career development programs, and health insurance. Every subsidiary included health insurance, and in some cases, life insurance. For relocated employees, every company provided housing, and in some cases, schooling for children. Cars and mobile phones for managers were also common. Other benefits like fitness, paid education, paid parking, and credit cards existed but were rare among these MNCs. Instead, companies strictly fulfill Russian labor law requirements, providing to their employees state retirement, illness days off, and 28 days of paid vacation. All the companies used 'immaterial' benefits like one-to-one meetings with the GM or 'well done' emails from the board of directors. 
Difference in working time showed US companies offering flexible hours and European companies requiring fixed hours. However, respondents from French companies expressed a desire to shift to flexible hours like at their HQ, and already provided some flexibility for managers.

The only common factor in HQ's influence on the benefits system were the expatriate packages diffused from HQ. The rest varied from extensive autonomy to standardized practices, indicating the important role of company strategy. As the HR manager of one US company stated, "Structure is diffused from HQ, but the amount is defined according to our assessment of performance and grade of the employee." The manager from another US company mentioned, "there is a 'library' in HQ, and the subsidiary is free to choose." The HR manager of a French company stated, "Principles of the social package and bonuses are partly diffused from HQ."

\section{Conclusions}

This research shows that the business systems approach developed by Whitley (1999) can be useful for studying post USSR transiting economies like Russia. The propositions derived from the theory found their application in practice. Among host country effects this study observed that weak information flow on the labor market and weak trust outside of the personal networks makes recruitment through personal contacts more appropriate in Russia. The underdeveloped vocational training in business and gaps in Soviet public education forces MNCs to provide extensive training in order to comply with international standards and requirements. In the case of local business, weak trade unions and therefore decentralized bargaining allows individual negotiation for compensation and high wage differentials; however, in MNCs the reward system is more strictly controlled by headquarters. The home 
country effects were quite powerful in MNCs originating from the USA, where levels of standardization were high. US companies are usually more standardized and tend to keep their business model unchanged across borders. Of course, such factors as the laws and regulations of the host country have to be respected by MNCs, forcing all of them to adapt. At this point, a company's HQ offers the structure for all HRM practices, but the application and adjustment of these practices usually depends on the subsidiary. There are some practices in US companies which stand out in their standardization, like the appraisal system, corporate culture, managerial training programs, grading structure for compensation and benefits, reward and recognition policy, and to some extent, recruitment. However, these global American practices were still adapted to the local environment. German and Sweden companies contrary were found to be the most adapted to the host context.

\section{References}

Almond, P. and Ferner, A. (2006). American Multinationals in Europe: Managing Employment Relations across National Borders, Oxford University Press, University of Oxford, UK.

Basareva, V.G. (2011) Gosudarstvennaya poddergka malogo biznesa: pomosh ili institutzional'naya lovushka? (State support of small business: help or institutional trap?) Paper presented at the Eleventh International Scientific Conference on Issues of Economic and Social development. Editor Yasin E.G. HSE. Moscow, N2 
Bjorkman, I. and Ehrnrooth, M. (2000). HRM in Western Subsidiaries in Russia and Poland. Journal of East-West Business, Volume 5, Issue 3, pages 63 - 79

Bjorkman, I., Fey, C., and Park, H. (2007a). Institutional theory and subsidiary HRM practices: evidence from a three country study. Journal of International Business Studies, Issue 38, pages 430-446

Bjorkman, I., Stahl, G. and Vaara, E. (2007b). Cultural differences and capability transfer in cross-border acquisitions: The mediating roles of capability complementarity, absorptive capacity, and social integration, Journal of International Business Studies, Vol. 38, pp. 658-672.

Blasi, J., Kroumova, M., and Kruse D., (1997). Kremlin capitalism: privatizing the Russian economy. New York: Cornell University Press.

Bonavia, T. and Marin-Garcia, J.A. (2011). Integrating human resource management into lean production and their impact on organizational performance, International Journal of Manpower, Vol. 32 No. 8, pp. 923-938.

Brewster, C., Wood, G. and Goergen, M. (2015) Institutions, unionization and voice: The relative impact of context and actors on firm level practice Economic and Industrial Democracy 36 (2): 195-214

Buckley, P. J. (2009). Internalisation thinking: From the multinational enterprise to the global factory, International Business Review, Vol. 18 No 3, pp. 224-235.

Butler, B. and Purchase, S. (2004). Personal Networking in Russian Post Soviet Life, Research and Practice in Human Resource Management, 12(1), 34-60.

Camiah N. and Hollinshead G. (2003). Assessing the potential for effective cross-cultural working between 'new' Russian managers and western expatriates. Journal of World Business 38, 245-261. 
Cheglakova, L.M. (2008) Профсоюз в транснациональной компании (на примере металлургического завода) Trade Union at Transnational Company (example of metallurgic factory). Экономическая социология (Economic Socioloty) 9, N 2, pages $46-55$

Chung, C., Sparrow, P., and Bozkurt, T. (2014). South Korean MNEs' international HRM approach: Hybridization of global standards and local practices, Journal of World Business, Vol. 49 No. 4, pp. 549-559

Clarke, S. (2004). A very Soviet form of capitalism? The management of holding companies in Russia. Post-Communist Economies (16)4, 405-422.

Clarke, S. and Metalina, T. (2000): Training in the new private sector in Russia. International Journal of Human Resource Management, 11, 19-36.

Cranfield Network on International Human Resource Management (2012), CRANET survey on comparative human resource management. International Executive Report 2011. Cranfield School of Management, UK.

DiMaggio, P. J. and Powell, W. (1983). The iron cage revisited": Institutional isomorphism and collective rationality in organizational fields, American Sociological Review, Vol. 48, pp. $147-60$.

Dixon, S., Day, M. and Brewster, C., (2014) Changing HRM systems in two Russian oil companies: Western hegemony or Russian spetsifika? International Journal of Human Resource Management 25 (22): 3134-3156

Dowling, P.J., Welch, D.E., and Schuler, R.S. (1999). International Human Resource Management: Managing People in a Multinational Context. Toronto: Southwestern College Publishing. 
Doz, Y. (1986). Strategic Management in Multinational Companies. Oxford Oxfordshire and New York

Edwards, T., Ferner, A. (2002) The renewed American challenge: A review of employment practice in US multinationals, Industrial Relations Journal, 33(2), 94-111.

Elenkov D. S. (1998). Can American Management Concepts work in Russia: A CrossCultural Comparative Study, California Management Review, 40, no. 4, p. 133-156.

Engelhard, J. and Nagele, J. (2003). Organizational learning in subsidiaries of multinational companies in Russia. Journal of World Business, 38, 262-277.

Ferner, A. (1997). Country of origin effects and HRM in multinational companies. University of Warwick. Human resource management journal - Vol. 7 no 1. P.19-37

Ferner, A. (2000). The embeddedness of US multinational companies in the US business System: implications for HR/IR. Leicester business school. Occasional paper 61.

Ferner, A.M. Almond, Phil, Clark, I., Colling, T., Edwards, T., Holden, Len., and MullerCamen, M., (2004). The dynamics of central control and subsidiary autonomy in the management of human resources: Case-study evidence from US MNCs in the UK. Organization Studies, 25 (3), pp. 363-391.

Ferner, A.M., Almond, P., and Colling, T. (2005). Institutional theory and the cross-national transfer of employment policy: The case of 'workforce diversity' in US multinationals. Journal of International Business Studies, 36 (3), pp. 304-321.

Fey, C. F. and Bjorkman, I. (2001). The effect of human resource management practices on MNC subsidiary performance in Russia, Journal of International Business Studies, Vol. 32 No. 1, pp. 59-75.

Fey, C. F., Björkman, I. and Pavlovskaya, A. (2000). The effect of human resource management practices on firm performance in Russia, International Journal of Human Resource Management, Vol. 11 No. 1, pp. 1-18. 
Fey, C., Engstrom P., and Bjorkman, I. (1999). Effective HRM practices for foreign firms in Russia. Organizational Dynamics. 28(4): 69-80

Galiullina, L.M. (2011). Vliyanie pripodnogo bogatstva na bednost' v Rossii. Eleventh International Scientific Conference on Issues of Economic and Social Development. Editor Yasin E.G. HSE. Moscow, N2

Goergen, M., Brewster,C., Wood, G.T. and Wilkinson, A ( 2012) Varieties of capitalism and investments in human capital Industrial Relations 51 (2): 501-527

Golovanova S.V., Kadochnikov C.M. (2011) Klasternie otnosheniya v rossii I regional'naya politica razvitiya klasterov. XI international scientific conference on issues of economic and social development. Editor Yasin E.G. HSE. Moscow, N3

Gurkov I., Zelenova, O., Goldberg A., and Saidov, Z. (2009). Human resource management in Russia compared to other countries. Mir Rossii, 3, 123-150. (in Russian)

Gurkov, I. (2002). Innovations and legacies in Russian human resource management practices: Surveys of 700 Chief Executive Officers. Post-Communist Economies, Vol. 14 No. 1, pp. 137-144.

Gurkov, I. and Zelenova O. (2008). Human resource management in Russia. In M.J.Morley, N.Heraty, S.Michailova (Eds.). Managing Human Resources in Central and Eastern Europe, 150-188.

Gurkov, I. and Filippov, S. (2013). Innovation processes in the Russian manufacturing subsidiaries of multinational corporations: an integrated view from case studies, Journal of East-West Business, Vol. 19 No. 4, pp. 260-290.

Gurkov, I. and Kossov, V. (2014). Combining contemporary and Soviet-Era management practices to achieve excellence at Knauf CIS, Global Business and Organizational Excellence, Vol. 33 No. 6, pp. 21-34. 
Gurkov, I. and Settles, A. (2013). A dominant archetype of the HRM system in Russian industrial companies in post-recession times, International Journal of Human Resource Management, Vol. 24 No. 19, pp. 3630-3643.

Gurkov, I. and Zelenova, O. (2011). Human resource management in Russian companies, International Studies of Management and Organization, Vol. 41 No. 4, pp. 65-78.

Gurkov, I. B., Morgounov, E.B., Settles, A.M. and Zelenova, O.I. (2014). HRM in Russia over a Century of Storm and Turmoil: A Tale of Unrealized Dreams, in Kaufman, B.E. (Ed.), The Development Of Human Resource Management Across Nations: Unity and Diversity, Cheltenham: Edward Elgar Publishing, pp. 363-386.

Gurkov, I., Zelenova, O. and Saidov, Z. (2012). Mutation of HRM practices in Russia: An application of CRANET methodology, International Journal of Human Resource Management, Vol. 23 No. 7, pp. 1289-1302.

Hall, P.A. and Soskice, D. (2001). An introduction to varieties of capitalism. In P.A. Hall and D. Soskice (Eds.), Varieties of Capitalism: The Institutional Foundations of Comparative Advantage. Oxford: Oxford University Press, 1-70.

Hanson, P. and Teague, E. (2005). Big business and the state in Russia. Europe-Asia Studies, 57(5), 657-680.

Hofstede, G. (1980). Culture's consequences: International differences in work-related values. Newbury Park, CA: Sage.

Kalabina E.G. (2011) Polotika voznagragdeniya personala organizazii v sisteme vnutrennego rinka truda: paternalism versus effectivnist'. XI international sientific conference on issues of economic and social development. Editor Yasin E.G. HSE. Moscow, N2 
Kets de Vries, M.F.R. (2001). The anarchist within: Clinical reflections on Russian character and leadership style, Human Relations, Vol. 54 No. 5, pp. 585-627.

Kozina, I.M. (2009). Корпорации, трудовые отношения и профсоюзы - вариант России (Corporations and Trade Unions - case of Russia). Мир России: Социология, этнология (World of Russia: sociology, ethnology) N1, 144-163

Latukha, M. (2015). Talent management in Russian companies: Domestic challenges and international experience, International Journal of Human Resource Management, Vol. 26 Is. 8, pp. 1051-1075.

Lawler, E. J. (1992). Affective Attachments to Nested Groups: A Choice Process Theory. American Sociological Review 57: 327-339.

Lunnan, R., Lervik, J.E.B., Traavik, L.E.M., Nilsen, S.M., Amdam, R.P., and Hennestad, B.W. (2005). Global transfer of management practices across nations and MNC subcultures, Academy of Management Executive, Vol. 19 No. 2, pp. 77-80.

Martinez Jon I., Jarillo J. Carlos (1989). The Evolution of Research on Coordination Mechanisms in Multinational Corporations. Journal of International Business Studies, Vol. 20, No. 3, pp. 489-514

May, R., Young, C.B., \& Ledgerwood, D. (1998). Lessons from Russian human resource management experience. European Management Journal, 16: 447-459.

May, R., Puffer, S.M., and McCarthy, D.J. (2005). Transferring management knowledge to Russia. A culturally based approach. Academy of Management Executive, 19(2) 24-35.

Mizruchi, M.S. and Fein, L.C. (1999). The social construction of organizational knowledge: A study of the uses of coercive, mimetic, and normative isomorphism, Administrative Science Quarterly, Vol. 44 no. 4, pp. 653-683. 
Morschett, D., Schramm-Klein H., and Zentes J. (2010). Strategic International Management: Text and Cases. MIR: Management International Review, Vol. 50, No. 3, pages 399401, Springer

Muller, S. L., and Clarke, L. D. (1998). Political-economic context and sensitivity to equity: Differences between the United States and the transition economies of Central and Eastern Europe. Academy of Management Journal, 41(3), 319-329.

Oshchepkov, A., Kholodilin, K., and Siliverstovs, B. (2009). The Russian Regional Convergence Process: Where Does It Go? Discussion Papers. Deutsches Institut für Wirtschaftsforschung. Berlin.

Poor, J., Karoliny, Z., Dobrai, K., Slavic, A., Kerekes, K., Farkas, F. and Engle Sr., A.D. (2014). Factors influencing human resource management solutions at subsidiaries of multinational companies in Central and Eastern Europe, Journal of East-West Business, Vol. 20 Iss. 2, pp. 93-119.

Puffer, S. and McCarthy, D. (2007). Can Russia's state-managed, network capitalism be competitive? Institutional pull versus institutional push. Journal of World Business 42, $1-13$.

Rugman, A.M. and Verbeke, A. (2004) A perspective on regional and global strategies of multinational enterprises Journal of International Business Studies 35 (1) pp. 3-18

Schmitt, M., Sadowski, D. (2003). A cost-minimization approach to the international transfer of HRM/IR practices: Anglo-Saxon multinationals in the Federal Republic of Germany, International Journal of Human Resource Management, Vol. 14 No. 3, pp. 409-430.

Shekshnia S. (1994): Managing People in Russia: Challenges for Foreign Investors, European Management Journal 12, p. 298-305.

Shekshnia, S. (1998). Western multinationals' human resource practices in Russia. European Management Journal, 16: 460-465. 
Shen, J. and Edwards, V. (2006). International Human Resource Management in Chinese Multinationals, Routledge, London, UK.

Sippola, M. (2009). The two faces of Nordic management? Nordic firms and their employee relations in the Baltic States, International Journal of Human Resource Management, Vol. 20 No. 9, pp. 1929-1944.

Sippola, M. (2011). Nordic subsidiaries in the Baltic States: Is model transfer possible?, Employee Relations, Vol. 33 Iss 4, pp. 356-374.

Sudharshan, D., Furrer, O. and Arakoni, R.A. (2015). Robust imitation strategies, Managerial and Decision Economics, Vol. 36 No. 3, pp. 139-157.

Tempel, A., Wachter, H., and Walgenbach, P. (2006). The comparative Institutional approach to human resource management in multinational companies. In Geppert, M., Mayer, M. (2006). Global, National And Local Practices in Multinational Companies. Palgrave.

Tüselmann, H.-J., Mcdonald, F., Heise, A. (2002). Globalisation, nationality of ownership and employee relations: German multinationals in the UK, Personnel Review, Vol. 31 No. 1-2, pp. 27-43.

Tüselmann, H.-J., McDonald, F., Heise, A. (2003). Employee relations in German multinationals in an Anglo-Saxon setting: Toward a Germanic version of the AngloSaxon approach? European Journal of Industrial Relations, Vol. 9 No. 3, pp. 327-349.

Vlachoutsicos, C. and Liargovas, P. (1999). Barriers to Transition of Enterprises in BSEC Countries: From Central Planning to Market Economy. In Southeast European Year book, $1997-98$, pp. $293-318$ 
Vo, A.N., and Rowley, C. (2010). The internationalization of industrial relations? Japanese and us multinational companies in Vietnam, Asia Pacific Business Review, Vol. 16 No. 1-2, pp. 221-238.

Wachter, H., Peters, R., Tempel, A., and Muller-Camen, M. (2003). The "Country of Origin Effects" in the cross-national management of buman resources. Reiner Hampp Verlag.

Walker, C. (2006). Managing vocational education and the youth labour market in postSoviet Russia. The International Journal of Human Resource Management, 17, (8), 1426-1440.

Whitley, R. (1999). Divergent capitalisms. The social structuring and change of business systems. Oxford university press.

Zavialova, E., Kosheleva, S. and Ardichvili. A. (2011). Human resource management and development practices in indigenous Russian companies and foreign MNCs: A comparative analysis, International Journal of Human Resources Development and Management, Vol. 11 No. 2-4, pp. 179-193.

Zheng, Y. (2014). Managing Human Resources in China: The View From Inside Multinationals, Cambridge University Press, Cambridge, UK.

Zhukova, M., and Korotov, K. (1998). Ot "sovetskogo otdela kadrov" - k cluzhbe upravleniya chelovecheskimi resursami [From a personnel department in the Soviet Union to a human resources department in Russia]. Chelovek I Trud, 8: 88--90.

Zhulzhenko, E. 2012. Human resource management and labour relations in post-transitional Russia (Discussion paper SP III 2012-303). Location: WZB Berlin Social Science Center. Retrieved from: http://hdl.handle.net/10419/57098 
Zudin, A.U. (2011). Assoziazii I koordinaziya vzaimodeistviya Rossiyskogo biznesa I gosudarstva. Eleventh International Scientific Conference on Issues of Economic and Social Development. Editor Yasin E.G. HSE. Moscow, N3 